\title{
Activization of Innovative Activities of Russian Commercial Banks
}

Olesya A. Stroeva

Russian Presidential Academy of National Economy and Public Administration, Moscow, Russian Federation

Natalya V. Sukhorukova

Russian Presidential Academy of National Economy and Public Administration, Moscow, Russian Federation

Aleksandr A. Tsvyrko

Russian Presidential Academy of National Economy and Public Administration, Moscow, Russian Federation

Tatyana N. Ivashchenko

Russian Presidential Academy of National Economy and Public Administration, Moscow, Russian Federation Email: stroeva-olesya@mail.ru

\section{Doi:10.5901/mjss.2015.v6n3s6p201}

\section{Abstract}

In the article the authors use systemic and historic analysis to determine the significant stages of formation and development of the Russian banking system. The authors study the monetary policy of the Bank of Russia and substantiate its influence on activization of innovative activities of commercial banks which determined the stability and reliability of the whole banking system. Despite the preconditions for activization of innovative processes in the banking sector, there still remains a range of unsolved problems. That's why the authors allocated the key factors which allow reaching rapid development and allow the Russian banking sector to become competitive in the global banking society. As a result of the conducted study of modern tendencies that take place in the Russia's economy and analysis of innovative activities of commercial banks and with the help of methods of scientific generalization, the authors substantiate the directions of development of innovative activities of commercial banks. The main of them are: development of electronic banking technologies, increase of quality and accessibility of banking services on the basis of development of modern types of customer service and improvement of security of banking business. It is found that as of now, the top-priority directions of activities of the Bank of Russia are development of national payment system and system of online banking.

Keywords: commercial banks, monetary policy, banking innovations, banking system, banking technologies.

\section{Introduction}

At present, the task of the Russian economy is to pass to a new stage of development due to diversification of production and modernization of financial system. One of the ways to do that is the economy's transfer to innovational path of development. A significant role in the formation of this process belongs to banking system of the Russian Federation, in particular, the Central Bank of the RF and commercial banks, which not only create and implement new products but form the financial stability in the country, allocate resources, and support the currency sovereignty. However, within the current changes in the financial market, the banking sector lacks instruments that facilitate quick and effective solutions various problems. This solution is represented by implementation of banking innovations.

Innovations, as an effective instrument of development of banking sector, allow, firstly, adapting foreign experience to the conditions of banking sector of the RF as to quick reaction to current changes in the economy; secondly, expanding the range of banking services, using modern technologies; thirdly, raising the efficiency of banking business; fourthly, substantiating the main tendencies of development of the banking system of the RF. Eventually, the use of banking innovations will facilitate the formation of a new paradigm of financial market of Russia on the basis of use of knowledge and innovations, as the most important economic resources. These aspects cause the actuality of the chosen topic (Sibirskaya, Stroeva, Serebrykova, Petruchina, 2014). 


\section{Research Methods}

Activization of innovative activities of Russian commercial banks is determined by general tendencies of development of the banking sector. In this regard, a special attention should be paid to analysis of current changes in the development of the banking sector under the influence of macro-economic conditions.

While analyzing the banking system, several significant stages of its evolutional development should be distinguished.

The first stage is 1990-1998. It is characterized by formation of Russia's banking system and by crisis tendencies in economy and banking sector. During the analyzed period, the real assets of commercial banks decreased by $35 \%$ under the influence of inflation, resource base of bank decreased by 9 times against the background of reduction of assets of population and enterprises (by 8.9 and 8.7 times, respectively), which led to negative tendencies in the banking system. At the same time, there is a growth of the volume of total income of bank by 9.9 times against the background of $35 \%$ reduction of GDP, and reduction of gross profit by $17 \%$. It should be noted that beginning from 1995 the tendency went to opposite direction, which became one of the signs of the crisis of the banking system (Barkovskiy, 2005).

The second stage - 1999-2007 - is characterized by the resources of commercial banks being directed for financing "extensive" growth of economy. The main sources of replenishing resources of commercial banks in 1999-2000 were money emission and enterprises' account. In 2001-2003 - population's savings. In 2004-2007, the banks actively borrowed assets in the external markets. This period is characterized by the banks' accumulating liquidity and by quickened rates of economy growth. The sphere of retail financial services of the banks included: mortgage lending, pension savings management, and life insurance. Investment activity was still very low. Free money assets were converted by population into currency. Relatively small volumes of deposits were caused by predominance of cash methods of payment, with plastic cards used mainly for cashing (around $90 \%$ of the operations) in ATM, or for using credit money for one-time purchases. At that, together with positive tendencies of development of the banking sector, there was a tendency for accumulation of banking risks.

The third stage of development of the banking sector - 2008-2014. It should be noted that 2008 became the most difficult one for the development of the banking sector. While the banking sector showed good indicators of its development at the beginning of the year, the middle of the year was marked with strengthened manifestation of crisis tendencies in the economy and reduction of main macro-economic indicators, which led to emergence of threat to its stability (problems with liquidity, performing of obligations, and runoff of population's deposits).

Thus, while the main source of formation of resource base of credit organizations in 1998 were the assets received from organizations (share in passive - 31.3\%), the population's assets began to dominate in 2009-2014. In 2012, the resource base of commercial banks formed under influence of structure deficit of liquidity and complicated situation in the external markets. Only the large banks had the access to external sources in 2012. In whole, credit organizations formed the resource base by means of internal market, offering deposits for higher rates. Despite crisis tendencies in economy in 2012, the stability of banking sector was reached with the help of customers' trust, and liquidity was achieved by means of increase of assets on accounts.

Year 2010 was characterized by overcoming of consequences of the global financial crisis. Resource base of the banks formed by means of inflow of customers' assets. Recovering of effective demand led to increase of customers' financing against the background of reduction of interest rates (Tulaykov, 2011).

In 2012-2014, the development of banking operations took place under conditions of slow growth of the Russian economy, which predetermined certain reduction of dynamics of the banking sector. Thus, during 2011, the banking sector assets increased by $23.1 \%$, and during 2012 - by $18.9 \%$.

The banks' credit portfolio included mainly credits for population, and their share continued to grow. At that, the share of credits for enterprises and organizations decreased, which was caused by redistribution of the resources of commercial banks to the market of consumer crediting, reduction of the level of capital adequacy, problems with external financing of banking activity, and slow economic growth of the real sector of economy (Gadisova, 2011).

The number of existing credit organizations showed the reduction dynamics during the analyzed period. This was primarily caused by tougher control and regulation of commercial banks' activities by the Central Bank.

Thus, during 2010, the number of the banks decreased and constituted 1012, in 2011 - 978, in 2012 - 956, and in 2013 - 923. In 2014, the Central Bank of Russia conducted measures for strengthening of the banking sector and clearing it of financially unstable credit organizations which were not able to fulfill their obligations to customers and of banks involved in questionable financial operations.

While determining the possibilities for development of commercial banks, their sustainability, reliability, capability for developing and offering a wide range of financial services, it is necessary to consider the monetary policy of the Bank 
of Russia and substantiate its influence on activization of innovative activities of the Russian commercial banks (Zamyshlyaeva, 2007).

Evaluating the influence of monetary policy of the Bank of Russia on the development of innovative activities of commercial banks, it is necessary to view methods and mechanisms which facilitated the stability of bank sector, provided the highly qualified management of bank risks, capital adequacy, liquidity, and development of innovational product and services in the banking sector (Sibirskaya, Stroeva, Khokhlova, Oveshnikova, 2014).

Thus, during 1990-1994, there was observed a range of negative tendencies in economy: unstable financial position of state budget policy, financial insolvency of the real sector of economy, which consisted in non-repayment of bank credits and reduction of profitability of banking sector. Due to these processes, the activity of the Bank of Russia was directed, firstly, at stabilization of the banking sector; secondly, at formation of mechanisms of credit emission; thirdly, at the reduction of the ruble exchange rate; fourthly, at accumulation of currency savings. All these measures led to support for the banking sector, balance of demand and offer for credit resources, and high level of banks' profits by means of use of cheap centralized credits (Shcherbakova, 2004).

Besides stabilization of macro-economic indicators, the Bank of Russia conducted an active policy of developing noncash transactions, implementing the rules of performing payment operations. Despite the absence of laws on payment systems, the implemented mechanisms of influence gave the Russian commercial banks the possibility to actively implement payment cards of foreign payment systems (Zazirniy, 2012).

In 1994 - 1996, within the development of new policy for support for the banking sector, the Bank of Russia began giving credits for commercial banks on the basis of credit auctions, REPO operations with reference to discount rate of the central Bank, and use of obligatory reservation of funds. One of the innovations of the banking sector at the beginning of 1990s was implementation of lombard loans in the activity of the Bank of Russia.

It should be noted that the development of the bank sector was also caused by increase of population's deposits. However, the main source of formation of money supply of commercial banks became operations with state securities, so called state treasury bills, and external loans, namely, Eurobonds, syndicated lending, etc.

The crisis of 1998 showed the distinctive threats for developing banking system of Russia, the main of which is instability of financial position of many commercial banks, consisting in currency liabilities of the largest banks of the RF. Moreover, this tendency was caused by absence of infrastructure, necessary for recovering of banking system (Kondrashov, 2012).

The main directions for stabilization of the banking system and its further development were recovering of the payment system and protection of the depositors' interests. The Central Bank of Russia began supporting the liquidity of commercial banks by transferring of liabilities to customers-individuals as to bank deposit contracts, made before September 1998. For this purpose, the following banks were chosen: Rossiyskiy Kredit OJSC, Mosbiznesbank OJSC, Promstroybank OJSC, Group MENATEP, SBS-Agro, CB Most-bank OJSC. In future, this mechanism was used for all commercial establishments.

In 2003, within monetary policy, there was conducted a process of implementation of innovations for performing activities of regulator, which consisted in experiment for optimization of activities of the Bank of Russia. The experiment led to the development of methodology for functional and technological standards of the Central Bank, description of processes and main direction of activities of the Bank of Russia in mid-term, and creation of web-site devoted to the process technologies.

In 2004, the Bank of Russia, according to the strategy for development of the banking sector of the Russian Federation until 2008, for the purpose of strengthening of trust in the banking system and its further development, there was passed a range of acts of law. The laws that influenced the improvement of activities of credit organization were passed in 2004.

In 2005, one of the most important tasks of the Bank of Russia was creation of the system of online gross payments for large and rapid payments (RTGS system). Solving these problems facilitated the reduction of risks during payment in this system, efficiency of realization of monetary policy, creation of conditions for unification with international payment systems. The Bank of Russia paid special attention to the project of provision "On noncash payments in the Russian Federation". Creation of a new regulatory act required the development and systematization of rules and organizational peculiarities for noncash payments within payment systems, which further ensured the standardization of requirements for the order of noncash payments.

According to this document, there were created conditions for the further development of the market of payment cards. It their turn, commercial banks received the possibility to flexibly implement new payment services (Usoskin \& Belousova, 2012).

As a result of the passed law, the number of payments cards in Russia increased by $55.5 \%$ in 2005 . The number 
(41.4\%) and volume (43.5\%) of payments also increased quickly. Credit organizations expanded the types of their services and implemented new ones with the usage of payments cards, which allowed modernizing the banking infrastructure. As a result of these measures, the share of noncash payments in Russia increased (2005 - by 16.7\%, $2006-18.6 \%)$.

In 2006-2007, the active development of informational technologies facilitated the increase of the number of customers of Russian banks by means of using the technology of e-banking.

Implementation of new services and methods of remote access in commercial banks, use of passwords for entering the system, and technologies of digital signature allowed providing the protection of interests of commercial banks' interests. A legal aspect of this protection became the creation of the Standard of the Bank of Russia. "Provision of informational security of organizations of the banking system of the Russian Federation. General provisions". STO BR IBBS-1.0-2006". This act introduced detailed conditions of minimization of risks during use of e-banking by credit organizations (Prosalova \& Nikolaeva, 2014).

In the following years, the measures held by the Bank of Russia ensured the increase of credit organizations that provided payment services for remote access funds (increase from $25.3 \%$ in 2008 to $31 \%$ in 2009) and transactions (2007 - RUB 3 trillion, 2008 - RUB 882.3 trillion).

During 2007-2008, there was an increase of the number of bank cards (increase by 19.8\%). Around 2.1 billion operations for the sum of RUB 9.1 trillion were performed in the Russian Federation. Despite the fact that the population still preferred to use payment cards for cash withdrawal, the positive dynamics of development of noncash payments through bank cards continued, which was caused by large-scale implementation of payroll cards, various bonuses, and charity.

\section{Results}

Development of the internet-banking was connected with the usage of marketing approaches in strategic planning of banking activities. Once again, it emphasizes the development of credit organizations on the basis of innovational methods of planning the activities which were not used by the banks before. In 2008-2001, there was an increase of transaction payments in the Internet by $24.5 \%$.

At that, 2008 became a very difficult year for the Russia's banking system. Financial crisis, outflow of capital, reduction of stock prices, and problems with liquidity in the banking sector led to delays in payments and issue of deposit funds and to bankruptcy of many commercial banks. In order to stabilize the situation and prevent massive bankruptcy of the banks, the Bank of Russia reduced the norms of obligatory reserves and expanded the list of bank assets which were taken in pledge for refinancing. With new laws in work, the Central Bank could provide credits for the banks without guarantees, as a temporary measure.

In 2009, 16 banks had an access to them. During the crisis, the Central Bank of the Russian Federation provided loans for one, three, and nine months. Besides, the Bank of Russia made agreements with banks, according to which it could compensate up to $90 \%$ of losses of lending bank which emerged during interbank lending. At the beginning of 2009, such agreements were made with 13 largest banks. Besides, 369 commercial banks appealed to the Bank of Russia. In March 2009, interbank loans within such agreements were provided to 128 banks. Beginning from 2008, the Central Bank cancelled the license revocation, but used the sanction if financial parameters ceased to conform to requirements of the regulator due to not the bank's fault, but to objective external factors.

During recovering of the banking system of 2009-2011, the most popular form of innovative activities of the Russian banks was remote banking. The share of credit organizations that use remote services grows very quickly (Evdokimova, 2013).

While considering the payment system, used by legal entities, it is necessary to mark the service "Internet-client", which was used in $75.8 \%$ of the Russian banks. Individuals also used this service while performing payment operations. According to MForum Analytics, as of year-end 2010, the number of users of Internet-banking services in Russia exceeded 6 million people, and its penetration constituted more than 4\%, which is 3.5 times more than in 2008. Internetbanking is primarily used for performing such services as online-orders, international purchase payment, internal transactions, and budget \& tax payments.

Also, there is a positive tendency for development of innovational products, such as non-contact payment technologies. These types of innovative banking services include mobile payments (40.4\%), Internet payments (46.2\%), money transfers (3.2\%) (Figure 1). 


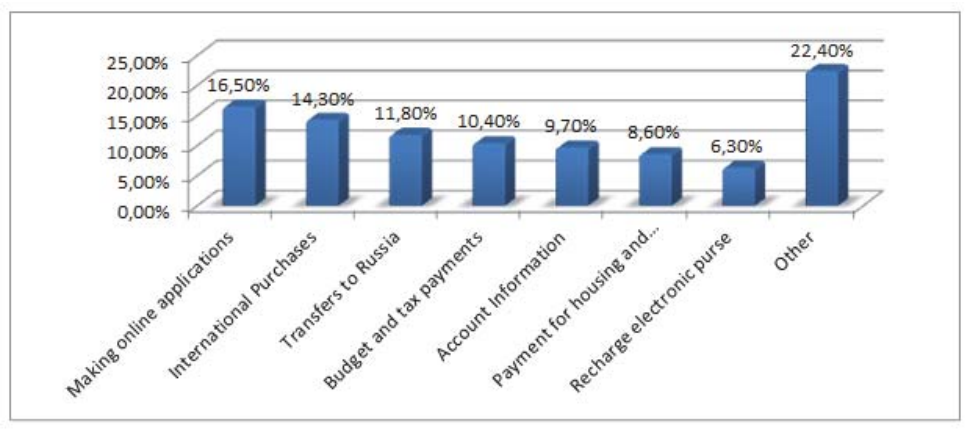

Figure 1 - Types of services performed through Internet banking, \%

Internet acquiring began to develop very quickly. Commercial banks started to pay more attention to analysis and evaluation of risks, implementing multilevel systems of fraud prevention and risk operations monitoring. The banking market featured non-banking services (for example, preparation of documents for business registration, legal support, and advertising through bank's partners), and creation of "institutes" of personal managers which are supposed to develop relations with customers, guide customers, and sell new products and services (Kondrashov, 2012).

It stands to mention the main mechanisms of influence of monetary policy of the Bank of Russia on the development of innovative activities of commercial banks, namely: transition to floating exchange rate, implementation of financial mega-regulator, and increase of the norm of obligatory reserve deposits of the Central bank of the RF.

In whole, these measures are aimed at the transfer of the tool of influence on economic development from the state to private entities. Exporters received a substantial market power - this gave them the opportunity to influence the national currency rate. At that, importers suffer losses, as uncertainty with the exchange rate of the ruble may lead to increase of cost of long-term contracts and, consequently, of production. Passing to floating exchange rate, the state forms a favorable economic climate for exporters. Unfortunately, the export market mostly consists of companies oriented at the sale of energy commodities, and they are interested in weakening of national currency; under conditions of floating exchange, this may lead to the stable cheapening of the ruble. This problem may be solved by deleting disproportions among export companies by means of attracting enterprises that are focused at sale of competitive production in the global market.

Implementation of financial instrument of regulation of inflation - financial mega-regulator from 2013 - means the transition from the policy of managing the rate of refinancing to its use as a tool of regulation of key interest rate. In longterm, this facilitates the foundation of favorable investment climate. Rational use of capital, i.e., investment of funds into large industrial projects, helps to create a flow of linear manufacturing of high-tech products with the use of received developments.

The Bank of Russia expands the possibilities for the banks to gain profit using the REPO instruments and crediting, gradually increasing the volumes of refinancing, including the use of new tools of refinancing against security of investment loans (Figure 2).

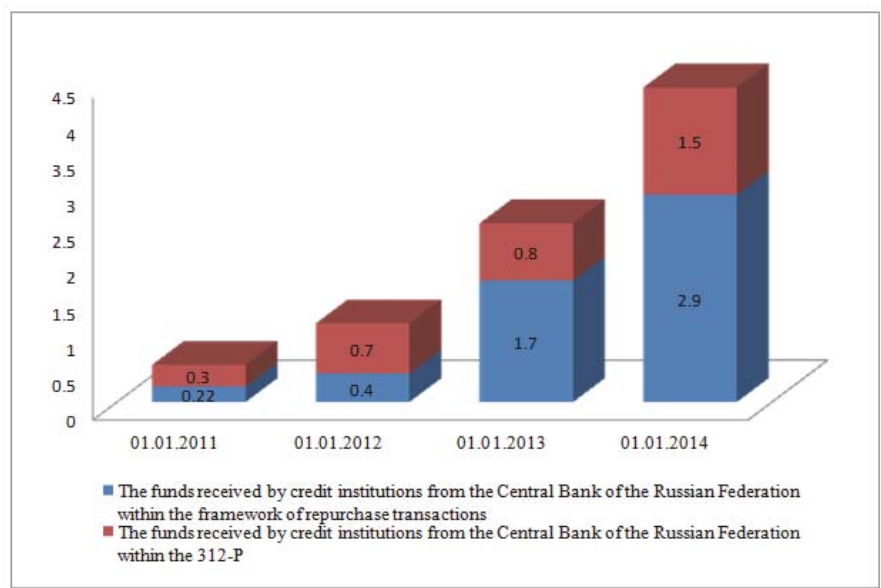

Figure 2 - Dynamics of repo with the Central Bank of the RF and crediting as part of Bank of Russia's Provision 312-P 
The conducted analysis and evaluation of activities of commercial banks for the period of 1990-2014 allows making conclusions that the results of the measures for stabilization of functioning of banking sector and its innovative development are:

1. Possibilities for increase of capitalization of the banking sector, by means of assets of various members of financial market (increase of quality of bank capital);

2. Increase of quality and accessibility of banking services on the basis of development of modern types of customer service;

3. Development of modern systems of corporate bank management;

4. Development of electronic banking technologies;

5. Development of new forms and methods of crediting and attraction of financial resources;

6. Development of new approaches to management and evaluation of risks, focused at modern financial practice and economic \& mathematical methods;

7. Development of informational \& technical infrastructure of interbank credit market;

8. Development of new forms and methods of disclosure of information on products and services of commercial banks;

9. Increase of security of banking business;

10. Accordance with international standards banking business and increase of competitiveness of the Russian banking sector.

Despite the created preconditions for activization of innovative processes in the banking sector, there still remains a range of unsolved problems:

1. Low resource base of most commercial banks, especially in view of necessity for provision of the real sector with long-term resources.

2. Instability of economy and financial sector.

3. High level of bank competition, accompanied by almost identical types of bank products and services.

4. Lack of highly qualified employees which can reproduce, support and sell innovational products and services.

5. Low competitiveness of the Russian commercial banks in comparison with foreign credit organizations, their products and services.

6. Most of credit organizations' lack of effective mechanisms of forecast, evaluation, and management of risks in the sphere of innovative activities.

It should be noted that these problems are primarily caused by the fact that during long period of development, the Russian banking sector used and adapted to its business the products and services of foreign banks which were innovational for the Russian market, while the technologies of foreign banks were far ahead of their Russian rivals. This is the reason for a gap between innovational development of the Russian and foreign banking sector (Smovzhenko \& Egoricheva, 2010; Grigorian, \& Manole, 2011; Hughes \& Mester, 2012; Guyn, 1999).

A vivid example is the development of payment system, namely, the payment cards market. Thus, payment cards of international systems appeared in the market of the Soviet Union in 1969. From that time on, payment cards began to appear in the Russian market, but the lack of necessary infrastructure for service, financial illiteracy, and inability of business subjects and population to use this payment system didn't allow the banking sector to quickly become a full member of international payments systems (North, 2002).

In 1990, only overdraft cards were issued for privileged clients of commercial banks. Beginning from 2000, commercial banks began to issue credit cards for mass-market customer. At that, the share of Russian payment systems in 2001-2002 was higher than the number of cards emitted by international payment system. Beginning from 2003, the number of emitted cards of international payment systems exceeded the number of the Russian ones. Thus, as of January 1, 2003, among total number of 15.4 cards, the share of Russian cards was 8.1 million (52.6\%), as of July 1 only $48 \%$.

Positive tendency of development of card business in formed under influence of dynamics of retail and wholesale payments with the help cards that change according to preferences of cardholders and is influenced by the development of infrastructure, which accepts the cards, and expansion of types of services, provided by credit organizations with the help of the cards. These factors led to the fact that the number and volume of operations with the use of the cards substantially increased over the nine months of 2005 , as compared to the similar period of the previous year. The number of operations increased by $55.7 \%$, their volume - by $50.1 \%$.

In 2005, the market share of international payment systems constituted: Visa International - 41\%, MasterCard/EuroCard - 20\%; market share of the Russian payment systems: Sberkart -9\%, "Zolotaya Korona" - 6\%, STB-card $-5 \%$ and Union Card - 8\%. 
As of October 1,2005, the number of trade and services organizations (around 121,000) and ATMs, used only for payment for services (around 13,200) increased by 37.4\%, as compared to October 1, 2004. The number of cash dispensing offices constituted 20,600, thus having increased by 14.4\% as compared to 2014 .

Thus, in 2005, there was a tendency for exceeding development of infrastructure that ensured the operations of noncash payment for goods and services with the use of cards. At that, rates of development of payment card infrastructure lag behind the rates of growth of emission of payment cards (emission growth - more than $52 \%$, infrastructure growth - about 37\%). In terms of absolute values and the number of ATMs and point-of-sale terminals per capita, the Russian market lagged behind, in comparison with the European countries.

Except for card products in Russia, the growth of the number of banks which provide the "mobile banking" services is observed. Beginning from 2003, the market of micro-payments, related to the functioning of the system of E-money, mobile and E-commerce, has also been growing.

One of the credit organizations with an active position on this market is St.Petersburg's bank "Tavrisheskiy". In 2003, it was the first bank in Russia to file documents (together with Alkor group) with the Bank of Russia to acquire the right of emission and distribution of prepaid financial products emitted in electronic form and created the web-site PayCash. Beginning from 2005, the "Tavricheskiy" ban has been offering the service "mobile wallet" together with mobile operator "Beeline".

Using this service, a customer can pay for goods or services from any place of the city or country with mobile connection and sufficient money on the SIM-card of the mobile phone, the number of which is used as an identifier of the client.

The role of the Bank of Russia in the development of this market in this period should be noted. Thus, according to the Law on the Central Bank (Article 3), the Bank of Russia is responsible for security, reliability, and efficiency of functioning of the payment system. That's why the Bank of Russia, within the development of the system of retail payments, is responsible for efficiency and safety of instruments and systems of retail payments, including payments with the use of electronic methods (payment cards). The task of the Bank of Russia consisted in creation of legal conditions for development of this market and increase of the share of noncash payments. Being a coordinator and intermediate between the banking sphere and public control and administration authorities, the Bank of Russia cooperates actively with the Federal Antimonopoly Service, for the conditions of functioning of the banking market and the market of payments cards to be transparent and keep the competitive conditions.

The following years marked the active development of payment systems.

Thus, in 2007, Visa issued the platform for commercial implementation of mobile payments services. The new product was a set of various tools, allowing the emitters of payment cards Visa (financial organizations), in cooperation with mobile operators, to implement the commercial services of mobile payments.

In 2008, there was an active growth of payments with the use of the Internet and mobile phone: the number of transaction grew by $70.6 \%$ up to 20 million, and the revenue grew by $65 \%$, reaching RUB 474 billion.

Thus, for example, in 2008 the total price of plane tickets paid in the Internet constituted RUB 10.6 billion, railway tickets - RUB 1.5 billion, which is 3.8 times more than in 2007.

The data in Table 1 shows the annual increase of bank cards issue.

Table 1 - Number of bank cards emitted by credit organizations, according to card types (thousand)

\begin{tabular}{|c|c|c|c|c|c|}
\hline \multirow{2}{*}{ Year } & \multirow{2}{*}{ Total number of bank cards } & \multicolumn{4}{|c|}{ including: } \\
\cline { 3 - 5 } & & \multirow{2}{*}{ Pay cards } & including: & \multirow{2}{*}{ Credit cards } & \multirow{2}{*}{ Prepaid cards } \\
\cline { 3 - 5 } & & & Pay cards with "overdraft" & & \\
\hline 2007 & 103,497 & 94,097 & - & 8,944 & 455 \\
\hline 2008 & 119,242 & 109,335 & 26,826 & 9,296 & 612 \\
\hline 2009 & 126,033 & 115,390 & 21,268 & 8,601 & 2,042 \\
\hline 2010 & 144,419 & 127,787 & 22,452 & 10,047 & 6,585 \\
\hline 2011 & 200,170 & 147,872 & 25,833 & 15,026 & 37,272 \\
\hline 2012 & 239,548 & 169,013 & 31,788 & 22,483 & 48,052 \\
\hline 2013 & 217,463 & 153,463 & 28,864 & 20,415 & 43,585 \\
\hline 2014 & 227,500 & 160,522 & 30,711 & 21,722 & 45,256 \\
\hline
\end{tabular}

Table 1 shows the dynamics of the number of issued bank cards.

Thus, the number of bank cards grew by 124,003 in 2007-2014, which is 2.2 times more than 2007 indicator. The 
year 2011 marked an especially huge increase.

Development of payment systems and infrastructure led to activity of population as to the use of bank cards for payments for purchases (Figure 3).

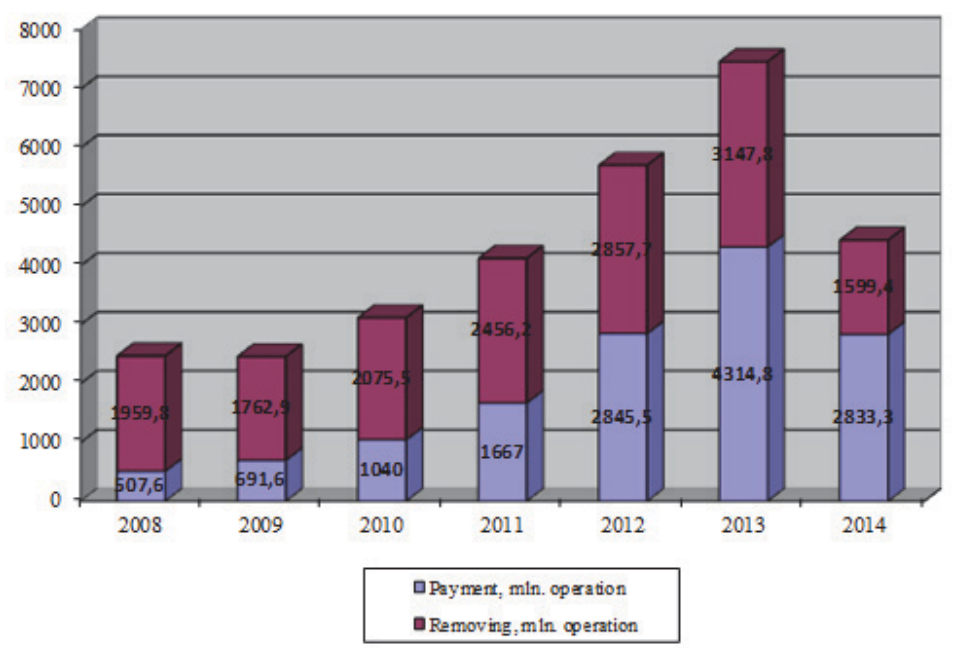

Figure 3 - Dynamics of card use by the population

While determining the activity of the Russian commercial banks as to implementation of innovations, it is necessary to conduct the analysis of innovational products of banks in 2013-2014.

Thus, Sberbank of Russia developed and implemented a means of payment for Odnoklassniki. Thus, the customers of Sberbank received the possibility to perform financial operations in Odnoklassniki social network itself.

The Trust Bank implemented the mobile version of the Internet - TRUST ONLINE. The "TRUST Mobile" application is available for owners of devices with iOS and Android and it copies the functions of the original system of onlinebanking. The similar application is used by the URALSIB Bank: "Mobile Bank" for smartphones with iOS and Android, which allows managing financing and performing bank operations.

The customers of Alfa Bank received the possibility to open the deposit accounts with various currencies with the help of Internet-bank "Alfa-Klik". Internet-bank "Alfa-Klik" features new function for assets control - "My expenses". With the help of this service, the customers of Alfa Bank can receive data as to ways and volume of spent assets during a certain period. Also, Alfa Bank announced the start of service for payments in the Internet-bank "Alfa-Klik" with one of the largest operators of online-booking - SENTURIA. Corporate clients of Alfa Bank received access to everyday account statements for SWIFT system in the format MT940 (via the Internet-bank "Alfa-Klik") for the accounts with Alfa Bank and other banks.

Bank24.ru realized the possibility for authorization in the system Internet-Bank (allows working with foreign economic activity, holdings, and accounting companies) through Facebook, Vkontakte, Twitter, or Linkedln, and gave its customers the possibility to issue invoices for contractors directly in the Internet-Bank "Tochka".

The system of E-payments CyberPlat ${ }^{\circledR}$ and Rosbank OJSC announced a significant expansion of payment possibilities within remote banking services.

Clients of St. Petersburg's Energomashbank received the possibility to open a range of traditional account via the Internet-Bank Energoline.

UniCredit Bank offered its customers an additional means for confirming operations in remote channels with the help of SMS. The SMS-key technology may be used for confirmation of operations in the Internet-Bank Enter.UniCredit, mobile version of the Internet-Bank PDA.UniCredit, and in the mobile applications Mobile.UniCredit for Android and iOS.

MTS Bank implemented the possibility for connection to the Internet banking systems via ATMS. Holders of any cards, emitted by MTS bank, can receive login and password for access in any device for remote service of the MTS Bank network in all regions. Before that, the customers had to visit the credit organization's offices.

Besides the development of Internet-banking and mobile banking, the quick growth of payment service infrastructure is also observed. Thus, the self-service terminals of Sberbank of Russia received new functions. More than $60 \%$ of devices of self-service without manual cash function provide a possibility to transfer money to other clients of Sberbank - for that, one must know only his cell phone number. There is also a possibility to perform transactions to 
MasterCard, emitted by another bank. A self-service terminal shows the operations performed in the Internet-Bank "Sberbank Online"; a customer can print the receipt, confirming the payment, and repeat the payment via the previously created pattern or activate the "Autopayment" service.

Customers of Moscow Credit Bank received the possibility to open account not only in the offices or via the MCB Online system, but with the help of terminals located in the offices of the credit organization.

The infrastructure of the centers for providing financial services also develops.

Thus, Bank Home Credit and QIWI Group create the centers for providing financial services on the basis of microoffices of the bank. There, the customers can use the crediting services, cancel a credit, and pay the services via QIWI terminals. In the micro-offices, the clients can take out a loan in cash, open a credit card, and use insurance services. Using the QIWI Terminals, the customers can cancel a credit, pay the services, and top-up Visa QIWI Wallet.

\section{Conclusion}

The analysis of implementation of banking innovations, showed above, proves a rather high innovational activity of the Russian commercial banks. However, it should be noted that the Russian banks' innovations are presented mainly by technological and process innovations and are based on catching-up development, as they are all available in the banking market of the developed countries of Europe and the USA.

At that, it should be noted that many Russian commercial banks have a huge potential which will allow reaching rapid development and will allow the Russian banking sector to become competitive in the global banking society. This should be facilitated by the range of factors of stable economic development of Russia: low inflation rates; strengthening of competition on the market of bank services; positive rates of economy growth; active development of competencies of bank employees as to development and implementation of new banking products and services; change of infrastructure of population's savings in favor of national currency; growth of financial literacy of the population.

\section{References}

Barkovskiy, V.V. (2005) Russia in the international banking society of the XXI century. Bankovskoe Delo, No.11, P.16.

Evdokimova, S.S. (2013) Systems of remote banking service as a tool of multiformat cooperation with a customer. Finansy i Kredit. No.39. Pp.37-44.

Gadisova, T.M. (2011) The role of financial innovations in the formation of competitive advantages of the Russian commercial banks. Kreativnaya Ekonomika. No. 9. Pp. 127-131

Grigorian, D., Manole, V. (2011) Determinants of Commercial Bank Performance in Transition: An Application of Data Envelopment Analysis, IMF Working Paper, 146.

Guyn, J. (1999) Next up for cell phones: Weaving a wireless Web. Fortune, N.-Y, P.25.

Hughes, J.P., Mester, L.J. (2012) Efficiency in banking: Theory, practice and evidence. Research Department, Federal Reserve Bank of Philadelphia, Working Paper.

Kondrashov, V.A. (2012) Key factors of risk of banking innovations in the Russian Federation. Finansy i Kredit. No. 13(493). P. 24.

Loskutov, A.Y. (2010) Meaning of financial innovations in the banking business. Bankovskie Uslugi. 5, Pp. 2-9.

North, D. (2002) Institutions, institutional changes and economic performance. - Cambridge, P.11.

Prosalova, V.S., Nikolaeva, A.A. (2014) Modern approach to banking innovations. Finansy i Kredit. No. 22(598), P.16.

Shcherbakova, G.N. (2004) Analysis and evaluation of banking business (on the basis of reports prepared according to the Russian and international standards). - M.: Vershina. 464 p.

Smovzhenko, T.S., Egorycheva, C.B. (2010) Innovational strategies of foreign banks. Dengi i Kredit. No. 8. Pp. 51-56.

Tulaykov, N.V. (2011) Role of banking innovations in post-crisis period. Finansy i Kredit. No. 9(441). P. 26.

Usoskin, V.M., Belousova, V.Y. (2012) Modern systems of interbank payments. Dengi i Kredit. No. 9. Pp. 24-30.

Sibirskaya, E.V., Stroeva, O.A., Khokhlova, O.A., Oveshnikova, L.V. (2014) An analysis of investment-innovation activity in Russia. Life Science Journal, No. 11 (7s). Pp. 155-158.

Sibirskaya, E.V., Stroeva, O.A., Serebrykova, N.A., Petruchina, E.V. (2014) The Contents and Structure of Innovative Activity in the Russian Economy. Asian Social Science, Vol. 10. No. 23. Pp. 51-60.

Zazirniy, A.K. (2012) Ambivalent effect of implementing innovations in the financial sphere. Vestnik Ekonomicheskoy Integratsii. No. 1. Pp. 80-85.

Zamyshlyaeva, K.V. (2007) Influence of technological innovations on the development of the banking sphere of Russia. Finansy i Kredit. No. 2(242). P. 29.

Zvarykina, E.B. (2010) Implementing innovational banking technologies. Finansy i Kredit. No. 38(422). P. 8. 
